\title{
Investigation of Physicochemical, Spectral, and Thermal Properties of Sodium Selenate Treated with the Energy of Consciousness (The Trivedi Effect ${ }^{\circledR}$ )
}

\author{
Mahendra Kumar Trivedi ${ }^{1}$, Alice Branton ${ }^{1}$, Dahryn Trivedi ${ }^{1}$, Gopal Nayak ${ }^{1}$, Aileen Carol Lee ${ }^{1}$, \\ Aksana Hancharuk ${ }^{1}$, Carola Marina Sand ${ }^{1}$, Debra Jane Schnitzer ${ }^{1}$, Rudina Thanasi ${ }^{1}$, \\ Eileen Mary Meagher ${ }^{1}$, Faith Ann Pyka ${ }^{1}$, Gary Richard Gerber ${ }^{1}$, Johanna Catharina Stromsnas ${ }^{1}$, \\ Judith Marian Shapiro ${ }^{1}$, Laura Nelson Streicher ${ }^{1}$, Lorraine Marie Hachfeld ${ }^{1}$, \\ Matthew Charles Hornung ${ }^{1}$, Patricia M. Rowe ${ }^{1}$, Sally Jean Henderson ${ }^{1}$, Sheila Maureen Benson ${ }^{1}$, \\ Shirley Theresa Holmlund ${ }^{1}$, Stephen P. Salters ${ }^{1}$, Parthasarathi Panda ${ }^{2}$, Snehasis Jana ${ }^{2}$, * \\ ${ }^{1}$ Trivedi Global, Inc., Henderson, Nevada, USA \\ ${ }^{2}$ Trivedi Science Research Laboratory Pvt. Ltd., Bhopal, Madhya Pradesh, India
}

Email address:

publication@trivedieffect.com (S. Jana)

${ }^{*}$ Corresponding author

To cite this article:

Mahendra Kumar Trivedi, Alice Branton, Dahryn Trivedi, Gopal Nayak, Aileen Carol Lee, Aksana Hancharuk, Carola Marina Sand, Debra Jane Schnitzer, Rudina Thanasi, Eileen Mary Meagher, Faith Ann Pyka, Gary Richard Gerber, Johanna Catharina Stromsnas, Judith Marian Shapiro, Laura Nelson Streicher, Lorraine Marie Hachfeld, Matthew Charles Hornung, Patricia M. Rowe, Sally Jean Henderson, Sheila Maureen Benson, Shirley Theresa Holmlund, Stephen P. Salters, Parthasarathi Panda, and Snehasis Jana. Investigation of Physicochemical, Spectral, and Thermal Properties of Sodium Selenate Treated with the Energy of Consciousness (The Trivedi Effect ${ }^{\mathbb{B}}$ ). American Journal of Life Sciences. Vol. 5, No. 1, 2017, pp. 27-37. doi: 10.11648/j.ajls.20170501.15

Received: February 6, 2017; Accepted: February 18, 2017; Published: March 7, 2017

\begin{abstract}
Sodium selenate is used for the prevention and treatment of various disorders like cancer, diabetes, inflammation diseases, etc. The objective of the current study was to evaluate the effect of The Trivedi Effect ${ }^{\circledR}$-Energy of Consciousness Healing Treatment (Biofield Energy Treatment) on physicochemical, spectral, and thermal properties of The Trivedi Effect ${ }^{\circledR}$ Biofield Energy Treated sodium selenate using various analytical methods such as PXRD, PSD, FT-IR, UV-vis spectroscopy, TGA, and DSC analysis. Sodium selenate was divided into two parts - one part was control without any treatment and another part was treated with The Trivedi Effect ${ }^{\circledR}$-Biofield Energy Healing Treatment remotely by eighteen renowned Biofield Energy Healers and defined as The Trivedi Effect ${ }^{\circledR}$-Energy of Consciousness Healing Treated sample. The PXRD analysis showed the significant alteration of the crystallite size of the treated sample in the range of $-36.36 \%$ to $133.24 \%$ as compared to the control sample. However, the average crystallite size of the treated sample was significantly decreased by $8.31 \%$ as compared to the control sample. Overall, the crystal morphology of the treated sample was different from the control sample. The particle sizes $\mathrm{d}_{10}, \mathrm{~d}_{50}$, and $\mathrm{d}_{90}$ values of the treated sample were significantly decreased by $3.40 \%, 9.75 \%$, and $8.52 \%$, respectively as compared to the control sample. Consequently, the surface area of the treated sample was significantly increased by $5.26 \%$ from the control sample. Both the control and treated FT-IR spectra indicated the presence of sharp and strong absorption bands at $887 \mathrm{~cm}^{-1}$ due to the $\mathrm{Se}=\mathrm{O}$ stretching. The $\mathrm{UV}$-vis spectroscopic analysis displayed that the wavelength for the maximum absorbance of both the control and treated samples were at 204.1 and $204.0 \mathrm{~nm}$, respectively. TGA analysis revealed that the total weight loss of the treated sample was reduced by $1.24 \%$ as compared with the control sample. The DSC analysis showed that the treated sample $\left(588.77^{\circ} \mathrm{C}\right)$ had higher melting point than the control sample $\left(588.60^{\circ} \mathrm{C}\right)$. The latent heat of fusion was reduced in the treated sample by $8.01 \%$ compared to the control sample. Thus, The Trivedi Effect ${ }^{\circledR}$-Biofield Energy Healing might lead to generate a new polymorphic (enantiotropic) form of sodium selenate which would be more soluble, bioavailable, and thermally stable compared with the untreated sample. The Trivedi Effect treated sodium selenate would be very useful to design better nutraceutical and/or pharmaceutical formulations that might offer better therapeutic response against inflammatory diseases, immunological disorders, stress, aging, infectious diseases, cancer, diabetes, heart diseases,
\end{abstract}


Alzheimer's disease, etc.

Keywords: Sodium Selenate, Biofield Energy Healing Treatment, Biofield Energy Healers,

Consciousness Energy Healing Treatment, The Trivedi Effect ${ }^{\mathbb{B}}$, PXRD, Particle Size, Surface Area, TGA, DSC

\section{Introduction}

Selenium (Se) is an essential trace nutrient for human body because it plays an important role in various biological functions such as catalytic effect on the reaction of intermediate metabolism and inhibition of the toxic effect of heavy metals. Selenium is present in the active site of enzymes like glutathione peroxidase and also in around 30 proteins as selenocysteine. It is a potent antioxidant and is involved in the cellular defense against free radicals $[1,2]$. Hence, deficiency of selenium produces several disorders such as cancer, heart diseases, viral diseases, diabetes, infectious diseases, degenerative ailments, etc. As there is a very restricted range between essentiality and toxicity, a little bit high concentration of selenium can affect the human health such loosing hair and nails, irritation of skin and eye [1-3]. The outcome of selenium is affected by numerous physical, chemical and biological factors, as these factors are related with the modifications in its oxidation state. It occurs naturally in four different oxidation states, i.e. $-2,0,+4$, and +6 . The different chemical forms of selenium can impact on its solubility and availability to organisms. Selenate is the most oxidized form among selenium compounds. It is less toxic and highly soluble in water [1-5]. Sodium selenate can be useful for the prevention and treatment of various ailments such as Alzheimer's disease, diabetes, etc. [6-8]. It is also used in the glass industry [9], an ingredient in some insecticides (against mites, aphids, and mealybugs) and some fungicides $[10,11]$. Sodium selenate can be used with vitamin $\mathrm{E}$ in the prevention of a many nutritional deficiency diseases. But, at high concentration, it causes cancers, deformation of hair and nails, giddiness, depression and nervousness [1]. Selenium methionine is a naturally occurring amino acid and is also the major nutritional source of selenium for human body. After absorption in the body, inorganic forms of selenium undergo reductive metabolism giving $\mathrm{H}_{2} \mathrm{Se}$ responsible for the production of selenoproteins [12]. Therefore, sodium selenate was considered as one of the component in a novel proprietary herbomineral formulation for the source of selenium ion. This herbomineral formulation is designed as nutraceutical supplement, and can be used for the prevention and treatment of various human disorders.

The human body can discharge the electromagnetic waves in the form of bio-photons that surrounds the body. This electromagnetic energy is generated from the continuous movement of the electrically charged particles (ions, cells, etc.) inside the body. This is collectively known as Biofield. Biofield Energy Healing practitioners have the ability to harness the energy from the environment or the "universal energy field" and can transmit into any living or nonliving object (s) around the earth. The process, where the objects receive the Biofield Energy Treatment and respond into useful way is called as Biofield Energy Healing [13-15]. Biofield (Putative Energy Fields) based Energy Therapies are used worldwide to promote health and healing. The National Center of Complementary and Integrative Health (NCCIH) has recognized and accepted Biofield Energy Healing as a complementary and alternative medicine (CAM) health care approach in addition to other therapies, medicines and practices such as natural products, deep breathing, yoga, Tai Chi, Qi Gong, chiropractic/osteopathic manipulation, meditation, massage, special diets, homeopathy, progressive relaxation, guided imagery, acupressure, acupuncture, relaxation techniques, hypnotherapy, healing touch, movement therapy, pilates, rolfing structural integration, mindfulness, Ayurvedic medicine, traditional Chinese herbs and medicines, naturopathy, essential oils, aromatherapy, Reiki, cranial sacral therapy and applied prayer (as is common in all religions, like Christianity, Hinduism, Buddhism and Judaism) [16]. From the study on the various fields include materials science [17, 18], pharmaceuticals $[19,20]$, nutraceuticals [21, 22], organic compounds [23-25], microbiology [26-28], agricultural [29, 30], biotechnology [31-33], genetics [34, 35], it has been proven that Biofield Energy Healing (also known as The Trivedi Effect ${ }^{\circledR}$ ) has the astounding capability for alteration of the characteristic properties of the several non-living materials and living organisms. From the scientific literature, it has been found that the bioavailability of inorganic selenium is lower than the organic forms of selenium such as selenium methionine. But, selenium methionine is easily oxidized to methionine selenoxide, which is poorly absorbed from the gut of the human body [12]. The physicochemical properties such as particle size, crystalline structure, crystallite size, surface area, etc. of a drug play an important role in bioavailability, as these factors have direct influence on the absorption characteristic and stability of the drug [36]. The particle size, specific surface area, crystalline nature, chemical and thermal behavior of an atom/ion might be altered by the Biofield Energy Healing Treatment (The Trivedi Effect ${ }^{\circledR}$ ) through possible mediation of neutrinos [37]. Literature mentioned that powder X-ray diffraction (PXRD), particle size distribution analysis (PSD), Fourier transform infrared (FTIR) spectrometry, ultraviolet-visible (UV-vis) spectroscopy, thermogravimetric analysis (TGA), and differential scanning calorimetry (DSC) analysis play an vital role for solving various problems encountered in industries for the pharmaceutical/nutraceutical formulation and developments [38]. Hence, the objective of the current study was to evaluate the effect of the Biofield Energy Healing Treatment on the physicochemical, spectral, and thermal properties of 
sodium selenate using various analytical techniques include PXRD, PSD, FT-IR spectrometry, UV-vis spectroscopy, TGA, and DSC.

\section{Materials and Methods}

\subsection{Chemicals and Reagents}

Sodium selenate was procured from Alfa Aesar, USA. All other chemicals used in the experiment were of analytical grade available in India.

\subsection{Energy of Consciousness Healing Treatment Strategies}

Sodium selenate was one of the components of the herbomineral formulation and it was used independently for the current analysis. The test compound was divided into two parts, one part of the test compound was treated with The Trivedi Effect ${ }^{\circledR}$ - Energy of Consciousness Healing Treatment by renowned Biofield Healers and defined as The Trivedi Effect ${ }^{\circledR}$ - Biofield Energy Treated sodium selenate, while the second part of the test compound did not receive any sort of treatment and defined as untreated or control sodium selenate. The Trivedi Effect ${ }^{\circledR}$ - was provided by the group of eighteen renowned Biofield Energy Healers who participated in this study and performed The Trivedi Effect ${ }^{\circledR}$ remotely. Eleven Biofield Energy Healers were remotely located in the U. S., four remotely located in Canada, two remotely located in Finland, and one of which was remotely located in Albania, while the test compound was located in the research laboratory of GVK Biosciences Pvt. Ltd., Hyderabad, India. This Biofield Treatment was provided for 5 minutes through Healer's Unique Energy Transmission process remotely to the test compound under the laboratory conditions. None of the Biofield Energy Healers in this study visited the laboratory in person, nor had any contact with the compounds. Similarly, the control compound was subjected to "sham" healers for 5 minutes, under the same laboratory conditions. The sham healer did not have any knowledge about The Trivedi Effect ${ }^{\circledR}$ - Biofield Energy Treatment. After that, the treated and untreated samples were kept in similar sealed conditions and characterized thoroughly by PXRD, PSD, FT-IR, UV-visible spectroscopy, TGA, and DSC analysis.

\subsection{Characterization}

\subsubsection{Powder X-ray Diffraction (PXRD) Analysis}

The XRD analysis was accomplished on PANalytical X'pert Pro powder X-ray diffractometer system. The X-ray of wavelength $1.54056 \AA$ was used. The data was collected in the form of a chart of the Bragg angle $(2 \theta) v s$. intensity, and a detailed table containing information on peak intensity counts, d value $(\AA)$, relative intensity (\%), full width half maximum (FWHM) $\left(\theta^{\circ}\right)$. From the XRD results, the crystallite size $(G)$ was calculated using X'pert data collector and $X$ 'pert high score plus processing software. The crystallite size $(\mathrm{G})$ was calculated from the Scherrer equation $[39,40]$. The method was based on the width of the diffraction patterns obtained in the X-ray reflected the crystalline region. The crystallite size $(\mathrm{G})$ was calculated by using the following equation 1 :

$$
\mathrm{G}=\mathrm{k} \lambda /(\mathrm{b} \operatorname{Cos} \theta)
$$

Where, $\mathrm{k}$ is the equipment constant $(0.5), \lambda$ is the $\mathrm{X}$-ray wavelength $(0.154 \mathrm{~nm})$; $\mathrm{b}$ in radians is the full-width at half of the peaks and $\theta$ the corresponding Bragg angle.

Percent change in crystallite size $(\mathrm{G})$ was calculated using following equation 2 :

$$
\% \text { change in crystallite size }=\frac{\left[\mathrm{G}_{\text {Treated }}-\mathrm{G}_{\text {Control }}\right]}{\mathrm{G}_{\text {Control }}} \times 100
$$

Where, $G_{\text {Control }}$ and $G_{\text {Treated }}$ are the crystallite size of the control and Biofield Energy Treated samples, respectively.

A total of $500.18 \mathrm{mg}$ of the control and treated samples individually were used for the analysis and prepared by back loading technique using the sample preparation kit. The sample was spread on the holder ring in sufficient quantity to fill the ring cavity. It was then pressed down using powder press block and scrap the powder that was in surplus using a glass slide to get densely packed specimen. Consequently, the bottom plate was placed onto the holder ring and clamp in position. The sample holder was then removed from the sample preparation table by turning it upside down. A smooth surface of sample was obtained to ensure optimum results.

\subsubsection{Particle Size Distribution (PSD) Analysis}

The average particle size and particle size distribution were analyzed using Malvern Mastersizer 2000, UK with a detection range between $0.01 \mu \mathrm{m}$ to $3000 \mu \mathrm{m}$. The sample unit was filled with dispersant medium and operated the stirrer at $2500 \mathrm{rpm}$. Alignment of the optics was done and taken the background measurement. After the background measurement, the sample was added into the sample unit with constant monitoring the obscuration and stopped the addition of sample, when the obscuration reached in between 15 and $20 \%$. When the obscuration was stable, the measurement was taken twice and the average was taken of two measurements. The average histogram of the two measurements was recorded. Along with histogram, the data will be presented in the Table format which include particle size $(\mu \mathrm{m})$. Also, the values for particle size $(\mu \mathrm{m})$ for at below $10 \%$ level $\left(\mathrm{d}_{10}\right), 50 \%$ level $\left(\mathrm{d}_{50}\right)$, and $90 \%$ level $\left(\mathrm{d}_{90}\right)$ were calculated from the histogram and the calculations such as surface area $\left(\mathrm{m}^{2} / \mathrm{g}\right)$ were done by using software Mastersizer 2000.

Percent change in particle size (d) for at below 10\% level $\left(\mathrm{d}_{10}\right)$, 50\% level $\left(\mathrm{d}_{50}\right)$, and $90 \%$ level $\left(\mathrm{d}_{90}\right)$ was calculated using following equation 3 :

$$
\% \text { change in particle size }=\frac{\left[\mathrm{d}_{\text {Treated }}-\mathrm{d}_{\text {Control }}\right]}{\mathrm{d}_{\text {Control }}} \times 100
$$

Where, $d_{\text {Control }}$ and $d_{\text {Treated }}$ are the particle size $(\mu \mathrm{m})$ for at below $10 \%$ level $\left(\mathrm{d}_{10}\right), 50 \%$ level $\left(\mathrm{d}_{50}\right)$, and $90 \%$ level $\left(\mathrm{d}_{90}\right)$ of the control and Biofield Energy Treated samples, respectively. 
Percent change in surface area (S) was calculated using following equation 4 :

$\%$ change in surface area $=\frac{\left[\mathrm{S}_{\text {Treated }}-\mathrm{S}_{\text {Control }}\right]}{\mathrm{S}_{\text {Control }}} \times 100$

Where, $\mathrm{S}_{\text {Control }}$ and $\mathrm{S}_{\text {Treated }}$ are the surface area of the control and Biofield Energy Treated samples, respectively.

\subsubsection{Fourier Transform Infrared (FT-IR) Spectroscopy}

FT-IR spectroscopy of sodium selenate was performed on Spectrum two (Perkin Elmer, USA) Fourier transform infrared spectrometer with the frequency array of 400-4000 $\mathrm{cm}^{-1}$ by using pressed $\mathrm{KBr}$ disk technique.

\subsubsection{Ultraviolet-visible Spectroscopy (UV-Vis) Analysis}

The UV-Vis spectral analysis was carried out using Shimadzu UV-2450 with UV Probe, Japan. The spectrum was recorded using $1 . \mathrm{cm}$ quartz cell that has a slit width of $1.0 \mathrm{~nm}$. The wavelength range chosen for recording the spectra were $190-800 \mathrm{~nm}$. The absorbance spectra (in the range of 0.2 to 0.9 ) and wavelength of maximum absorbance $\left(\lambda_{\max }\right)$ were recorded.

\subsubsection{Thermal Gravimetric Analysis (TGA)}

TGA analysis was performed using Instrument TGA Q50 (TA Instruments, USA) at a heating rate of $10^{\circ} \mathrm{C} / \mathrm{min}$ from room temperature i.e. $30^{\circ} \mathrm{C}$ to $900^{\circ} \mathrm{C}$ under nitrogen atmosphere (sample mass $10.477 \mathrm{mg}$ on platinum pan). In TGA, the weight loss for each step was recorded in grams as well as in percent loss with respect to the initial weight. Also, the value of onset, endset, and peak temperature for each step were recorded in TGA. Percent change in weight loss (W) was calculated using following equation 5 :

$$
\% \text { change in weight loss }=\frac{\left[\mathrm{W}_{\text {Treated }}-\mathrm{W}_{\text {Control }}\right]}{\mathrm{W}_{\text {Control }}} \times 100
$$

\subsubsection{Differential Scanning Calorimetry (DSC)}

Analysis was performed using the DSC Q20 (TA Instruments, USA) differential scanning calorimeter. $2.50 \mathrm{mg}$ of sample was weighed and sealed in alumina pan and equilibrated at $25^{\circ} \mathrm{C}$ and heated up to $650^{\circ} \mathrm{C}$ at the heating rate of $10^{\circ} \mathrm{C} / \mathrm{min}$ under nitrogen gas as purge atmosphere with the flow rate of 50 $\mathrm{mL} / \mathrm{min}$. The value for onset, endset, peak temperature, peak height $(\mathrm{mJ}$ or $\mathrm{mW})$, peak area, and change in heat $(\mathrm{J} / \mathrm{g})$ for each peak were recorded. Percent change in melting point $(\mathrm{T})$ was calculated using following equation 6 :

$$
\% \text { change in melting point }=\frac{\left[\mathrm{T}_{\text {reated }}-\mathrm{T}_{\text {control }}\right]}{\mathrm{T}_{\text {Control }}} \times 100
$$

Where, $\mathrm{T}_{\text {Control }}$ and $\mathrm{T}_{\text {Treated }}$ are the melting point of the control and treated samples, respectively.

Percent change in the latent heat of fusion $(\Delta \mathrm{H})$ was calculated using following equation 7 :

$$
\% \text { change in latent heat of fusion }=\frac{\left[\Delta \mathrm{H}_{\mathrm{Treated}}-\Delta \mathrm{H}_{\text {Control }}\right]}{\Delta \mathrm{H}_{\text {Control }}} \times 100
$$

Where, $\Delta \mathrm{H}_{\text {Control }}$ and $\Delta \mathrm{H}_{\text {Treated }}$ are the latent heat of fusion of the control and treated samples, respectively.

\section{Results and Discussion}

\subsection{Powder X-ray Diffraction (PXRD) Analysis}

The PXRD diffractograms of the both control and treated sodium selenate (Figure 1) showed very sharp and intense peaks indicating that both these samples were crystalline in nature.

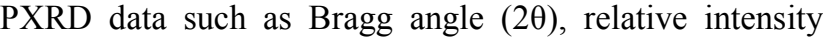
$(\%)$, full width half maximum (FWHM) $\left(\theta^{\circ}\right)$, and crystallite size $(G)$ for the control and treated sodium selenate are presented in the Table 1 . The crystallite size was calculated by the help of Scherrer equation [39, 40].

Where, $\mathrm{W}_{\text {Control }}$ and $\mathrm{W}_{\text {Treated }}$ are the weight loss of the control and Biofield Energy Treated samples, respectively.

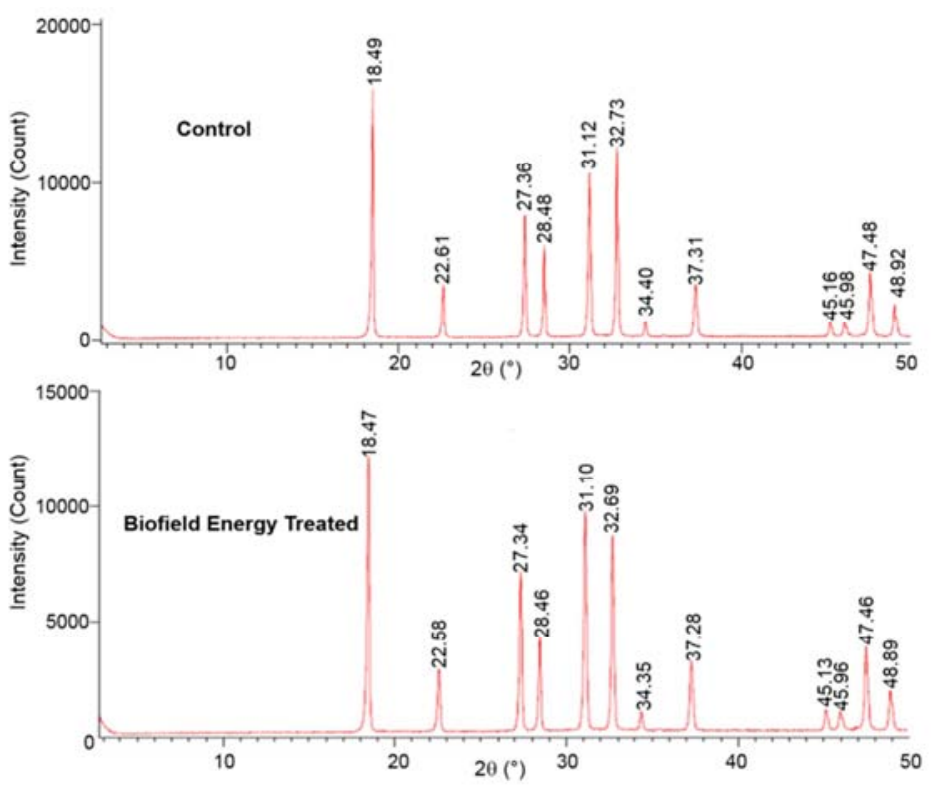

Figure 1. PXRD diffractograms of the control and Biofield Energy Treated sodium selenate. 
Table 1. PXRD data for the control and Biofield Energy Treated sodium selenate.

\begin{tabular}{|c|c|c|c|c|c|c|c|c|c|}
\hline \multirow{2}{*}{$\begin{array}{l}\text { Entry } \\
\text { No. }\end{array}$} & \multicolumn{2}{|c|}{ Bragg angle $\left({ }^{\circ} 2 \theta\right)$} & \multicolumn{2}{|c|}{ Relative Intensity (\%) } & \multicolumn{2}{|c|}{ FWHM $\left({ }^{\circ} 2 \theta\right)$} & \multicolumn{3}{|c|}{ Crystallite size (G, nm) } \\
\hline & Control & Treated & Control & Treated & Control & Treated & Control & Treated & $\%$ change \\
\hline 1 & 18.49 & 18.47 & 100.00 & 100.00 & 0.1004 & 0.1338 & 44.42 & 33.33 & -24.96 \\
\hline 2 & 22.61 & 22.58 & 21.16 & 22.50 & 0.1171 & 0.1506 & 38.34 & 29.81 & -22.25 \\
\hline 3 & 27.36 & 27.34 & 49.36 & 57.80 & 0.1004 & 0.1506 & 45.13 & 30.08 & -33.34 \\
\hline 4 & 28.48 & 28.46 & 36.98 & 33.96 & 0.1004 & 0.1506 & 45.24 & 30.16 & -33.34 \\
\hline 5 & 31.12 & 31.10 & 66.41 & 77.50 & 0.1171 & 0.1840 & 39.03 & 24.84 & -36.36 \\
\hline 6 & 32.73 & 32.69 & 69.76 & 70.28 & 0.1338 & 0.1673 & 34.29 & 27.42 & -20.03 \\
\hline 7 & 34.40 & 34.35 & 6.14 & 6.90 & 0.1338 & 0.1171 & 34.45 & 39.35 & 14.25 \\
\hline 8 & 37.31 & 37.28 & 21.33 & 25.18 & 0.1506 & 0.2007 & 30.86 & 23.15 & -24.97 \\
\hline 9 & 45.16 & 45.13 & 6.02 & 7.60 & 0.2342 & 0.1004 & 20.36 & 47.50 & 133.24 \\
\hline 10 & 45.98 & 45.96 & 5.67 & 6.85 & 0.1004 & 0.1171 & 47.64 & 40.85 & -14.27 \\
\hline 11 & 47.48 & 47.46 & 25.10 & 30.42 & 0.1673 & 0.1338 & 28.76 & 35.95 & 25.03 \\
\hline 12 & 48.92 & 48.89 & 12.52 & 14.33 & 0.2040 & 0.1428 & 23.72 & 33.88 & 42.84 \\
\hline 13 & \multicolumn{4}{|c|}{ Average crystallite size } & & & 36.02 & 33.03 & -8.31 \\
\hline
\end{tabular}

FWHM: Full width half maximum, ${ }^{*}$ denotes the percentage change in the crystallite size of Biofield Energy Treated sample with respect to the control sample

Table 1 showed the notable changes of the crystallite size of the treated sodium selenate with respect to the control sample. From the Table 1. (entry no 1), the most intense peaks for the control and treated samples were found at $2 \theta$ equal to $18.49^{\circ}$ and $18.47^{\circ}$, respectively. The crystallite size of the treated sodium selenate at $2 \theta$ equal to nearly $18.5^{\circ}$, $22.6^{\circ}, 27.3^{\circ}, 28.5^{\circ}, 31.1^{\circ}, 32.7^{\circ}, 37.3^{\circ}$, and $46^{\circ}$ (Table 1 , entry $1-6,8$, and 10$)$ were significantly $(14.27-36.36 \%)$ reduced with respect to the control sample. In contrast, at position $2 \theta$ equal to nearly $34.4^{\circ}, 45.1^{\circ}, 47.5^{\circ}$, and $48.9^{\circ}$ (Table 1 , entry $7,9,11$, and 12 ), the crystallite sizes of the treated sodium selenate were remarkably increased from $14.25 \%$ to $133.24 \%$ compared with the control sample. Overall, the average crystallite size of the treated sodium selenate was decreased by $8.31 \%$ as compared to the control sample. Beside these, other XRD parameters such as relative intensities of the XRD peaks in the treated sodium selenate were significantly altered as compared to the control sample. It has been reported that XRD relative intensity of each diffraction face on crystalline compound changes according to the crystal morphology [41]. Literature demonstrated that alterations in the XRD pattern provide the proof of polymorphic transitions [42]. Hence, changes in the crystallite size and relative intensities of XRD peaks revealed that the crystal morphology of the Biofield Energy Treated sample was modified from the control sample. Thus, it is anticipated that the change in the crystal morphology of the sodium selenate was due to the energy transferred through Biofield Energy Healing (The Trivedi Effect ${ }^{\mathbb{R}}$ ) and this probably introduced a new polymorphic form of sodium selenate. Crystal habit, size and even polymorphic form of a drug have an important effect on drug solubility, dissolution and bioavailability. Numerous examples in the scientific literature establish the impacts of alteration in crystal morphology on in vitro dissolution rate, with prospective for improving bioavailability [43]. So, it is inferred that The Trivedi Effect ${ }^{\circledR}$ - Biofield Energy Treatment might help for improving the bioavailability of sodium selenate.

\subsection{Particle Size Distribution (PSD) Analysis}

Particle sizes $\left(\mathrm{d}_{10}, \mathrm{~d}_{50}\right.$, and $\left.\mathrm{d}_{90}\right)$ and surface area of both the control and treated sodium selenate were explored and the results are presented in Table 2 . The size of the particles at below $10 \%$ level $\left(\mathrm{d}_{10}\right), 50 \%$ level $\left(\mathrm{d}_{50}\right)$, and $90 \%$ level $\left(\mathrm{d}_{90}\right)$ of the treated sodium selenate $\left(\mathrm{d}_{10}=4.27 \mu \mathrm{m}, \mathrm{d}_{50}=17.13\right.$ $\mu \mathrm{m}$, and $\left.\mathrm{d}_{90}=54.73 \mu \mathrm{m}\right)$ were significantly reduced by $3.40 \%, 9.75 \%$, and $8.52 \%$, respectively with respect to the control sample $\left(\mathrm{d}_{10}=4.42 \mu \mathrm{m}, \mathrm{d}_{50}=18.98 \mu \mathrm{m}\right.$, and $\mathrm{d}_{90}=$ $59.83 \mu \mathrm{m})$. The surface area analysis of both control and treated sodium selenate demonstrated that the surface area of the treated sodium selenate $\left(0.60 \mathrm{~m}^{2} / \mathrm{g}\right)$ was enhanced by $5.26 \%$ from the control sample $\left(0.57 \mathrm{~m}^{2} / \mathrm{g}\right)$.

Table 2. Particle size data $\left(d_{10,} d_{50}\right.$, and $\left.d_{90}\right)$ and surface area of the control and Biofield Energy Treated sodium selenate.

\begin{tabular}{lllll}
\hline Parameter & $\mathbf{d}_{\mathbf{1 0}}(\boldsymbol{\mu \mathbf { m }})$ & $\mathbf{d}_{\mathbf{5 0}}(\boldsymbol{\mu \mathbf { m }})$ & $\mathbf{d}_{\mathbf{9 0}}(\boldsymbol{\mu \mathbf { m }})$ & Surface $\operatorname{area}\left(\mathbf{m}^{2} / \mathbf{g}\right)$ \\
\hline Control & 4.42 & 18.98 & 59.83 & 0.57 \\
Biofield Energy Treated & 4.27 & 17.13 & 54.73 & 0.60 \\
Percent change* (\%) & -3.40 & -9.75 & -8.52 & 5.26 \\
\hline
\end{tabular}

*denotes the percentage change in the particle size data $\left(d_{10}, d_{50}\right.$, and $\left.d_{90}\right)$ and surface area of Biofield Energy Treated sample with respect to the control sample.

A lot of examples in the literature exhibited that particle size, shape and surface area of the compounds play vital role in the solubility, absorption, dissolution and bioavailability of the pharmaceuticals $[36,44,45]$. Reduction in particle size and higher surface area enhance the solubility of the solid particles as well as increase the dissolution rate and bioavailability [46]. Thus, it is predicted that The Trivedi Effect $^{\circledR}$ - Biofield Energy Treated sodium selenate might be 
absorbed in faster rate from the gut and thus, can offer more bioavailability than the untreated sample.

\subsection{Fourier Transform Infrared (FT-IR) Spectroscopy}

The FT-IR spectra of both the control and treated samples of sodium selenate are exhibited in Figure 2. Scientific literature reported that the water molecules which are incorporated into the lattice structure of the crystalline inorganic compounds harvest the characteristic absorption bands in the $3800-3200$ and $1700-1600 \mathrm{~cm}^{-1}$ regions due to the $\mathrm{O}-\mathrm{H}$ stretching and bending for the water molecules, respectively [47]. The control IR spectrum showed the O-H stretching and bending absorption bands at 3441, 1723, and $1640 \mathrm{~cm}^{-1}$, respectively. On the other hand, peaks for the O-
$\mathrm{H}$ stretching and bending of the water molecules in the treated sample were found at 3446, 1721, and $1641 \mathrm{~cm}^{-1}$.

The fingerprint region of the treated and control samples was remained unchanged. From the literature, it has been found that $\mathrm{M}=\mathrm{O}$ (metal-oxide) stretching absorption band for inorganic materials was found in the $1010-850 \mathrm{~cm}^{-1}$ region [47]. A sharp and strong absorption bands at $887 \mathrm{~cm}^{-1}$ were found in both the control and treated spectra due to the $\mathrm{Se}=\mathrm{O}$ stretching. The analysis revealed that structure integrity of treated sodium selenate remained unaffected compared with the control sample.

\subsection{Ultraviolet-visible Spectroscopy (UV-Vis) Analysis}

The UV-visible spectra of both the control and treated sodium selenate are shown in the Figure 3.
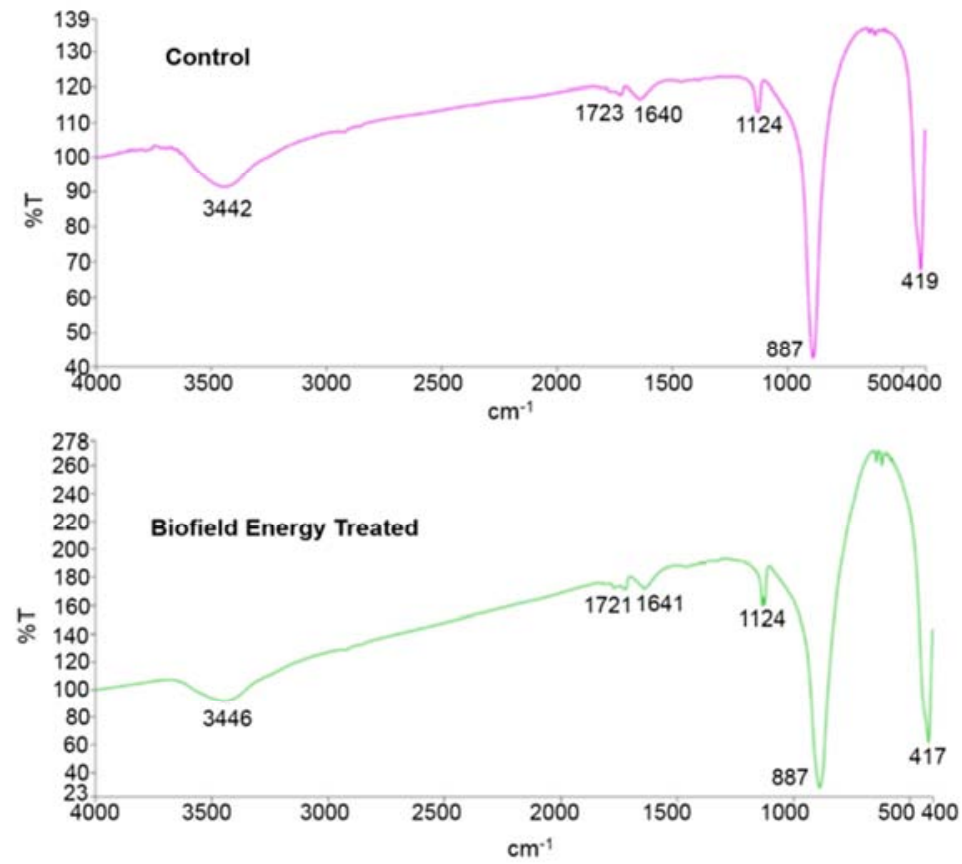

Figure 2. FT-IR spectra of the control and Biofield Energy Treated sodium selenate.
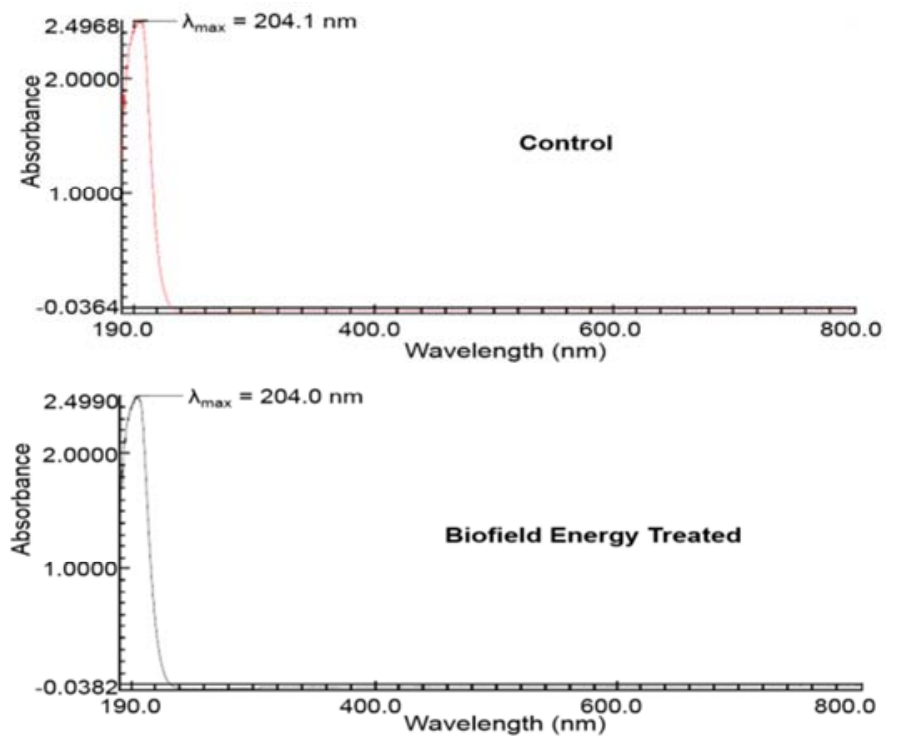

Figure 3. UV-vis spectra of the control and Biofield Energy Treated sodium selenate. 
The wavelength for the maximum absorbance $\left(\lambda_{\max }\right)$ of the control and treated sodium selenate were at 204.1 and $204.0 \mathrm{~nm}$, respectively and there was a minor move of absorbance maxima from 2.4989 in the control sample to 2.4994 in the treated sample. However, the $\lambda_{\max }$ of the treated sample was remained unchanged in comparison with the control sample. The UV absorbance happens due to the different type of energy transitions from the singlet to the singlet excited state such as $\sigma$ $\rightarrow \sigma^{*}, \mathrm{n} \rightarrow \pi^{*}$, and $\pi \rightarrow \pi^{*}$. These type of electronic transitions are occurred when the difference in energy between the lowest unoccupied molecular orbital (LUMO) and the highest occupied molecular orbital (HOMO) is significantly greater than the activation energy of the compound [48]. As. there was no change in the $\lambda_{\max }$ of the treated sample as compared to the control, it is anticipated that the structural configuration or activation energy of sodium selenate remained unchanged due to The Trivedi Effect ${ }^{\circledR}$ - Biofield Energy Healing Treatment.

\subsection{Thermal Gravimetric Analysis (TGA)}

The thermal stability of a solid compound plays an important role in the quality, efficacy, and safety in a drug formulation during the process, shipment, storage, and handling [49]. Hence, TGA and DSC analysis were used to examine the thermal stability of both the control and treated sodium selenate.

Table 3. Thermal degradation steps of the control and Biofield Energy Treated sodium selenate.

\begin{tabular}{|c|c|c|c|c|c|}
\hline \multirow{2}{*}{ Step } & \multicolumn{2}{|c|}{ Temperature $\left({ }^{\circ} \mathrm{C}\right)$} & \multicolumn{2}{|c|}{ Weight loss\% } & \multirow{2}{*}{ \% Change" } \\
\hline & Control & Treated & Control & Treated & \\
\hline $1^{\text {st }}$ step of degradation & 100.70 & 105.03 & 0.10 & 0.23 & 130 \\
\hline $2^{\text {nd }}$ step of degradation & 896.12 & 896.16 & 7.14 & 6.92 & -3.08 \\
\hline Total weight loss & - & - & 7.24 & 7.15 & -1.24 \\
\hline
\end{tabular}

'Denotes the percentage change in the weight loss of Biofield Energy Treated sample with respect to the control sample.

The TGA thermograms of both the control and treated samples and their thermal analysis data are shown in Figure 4. and Table 3, respectively. The TGA analysis showed two steps of thermal degradation of sodium selenate.
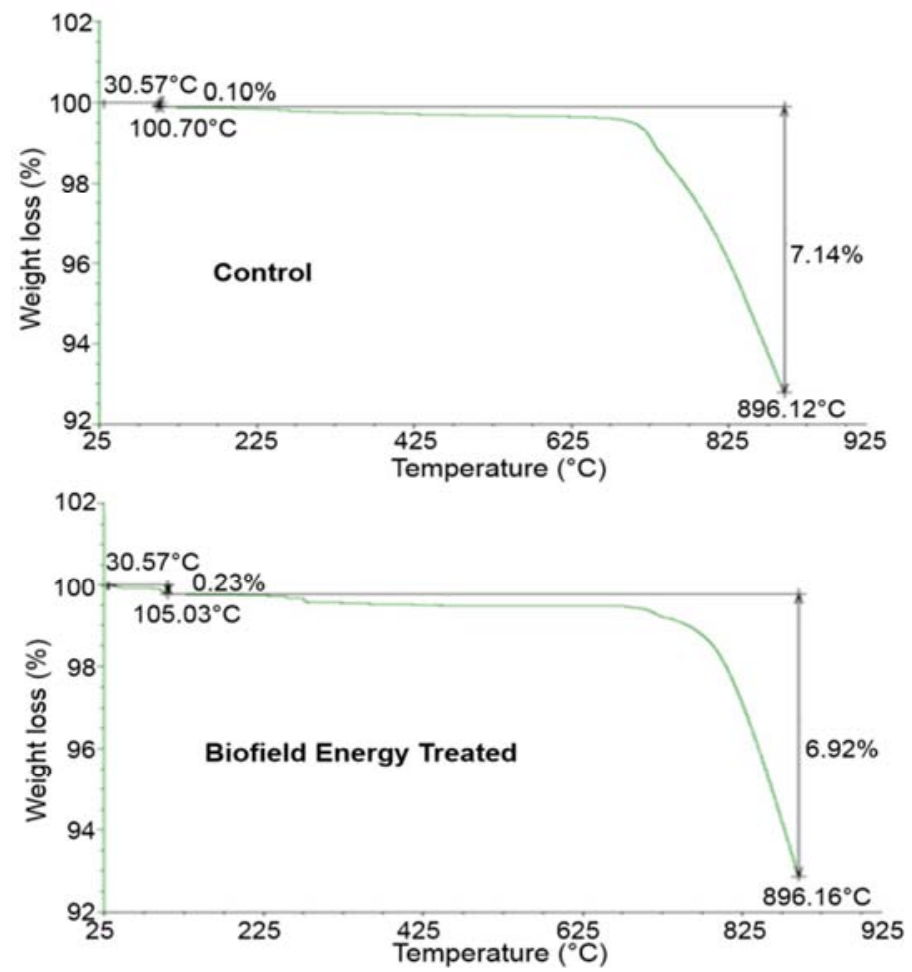

Figure 4. TGA thermograms of the control and Biofield Energy Treated sodium selenate.

In the $1^{\text {st }}$ step thermal degradation (Table 3), the weight loss of the sodium selenate $(0.23 \%)$ were increased by $130 \%$ from the control sample $(0.10 \%)$. In contrast, the weight loss of the treated sample $(6.92 \%)$ was reduced by $3.08 \%$ in the $2^{\text {nd }}$ step thermal degradation (Table 3 ) as compared to the control sample (7.14\%). However, the total weight loss (Table 3) of the treated sample was reduced by $1.24 \%$ from the control sample. It is then predicted that The Trivedi Effect ${ }^{\circledR}$ - Biofield Energy Treatment might improve the thermal stability of the sodium selenate.

\subsection{Differential Scanning Calorimetry (DSC) Analysis}

The DSC thermograms of both the control and treated sodium selenate are shown in Figure 5 and their DSC data 
are depicted in the Table 4.

The DSC thermogram of the treated sample displayed a sharp endothermic inflection at $588.77^{\circ} \mathrm{C}$ which may be the melting point of the sodium selenate and it was a slight $(0.03 \%)$ higher than the control sample $\left(588.60^{\circ} \mathrm{C}\right)$. Interestingly, the latent heat of fusion $(\Delta \mathrm{H})$ of the treated sodium selenate $(96.77 \mathrm{~J} / \mathrm{g})$ was lower by $8.01 \%$ from the control sample $(\Delta \mathrm{H}=105.2 \mathrm{~J} / \mathrm{g})$. Literature demonstrated that decreased particle size depress the latent heat of fusion [50]. As the treated sample has reduced particle size, it has lower latent heat of fusion compared with the control sample.
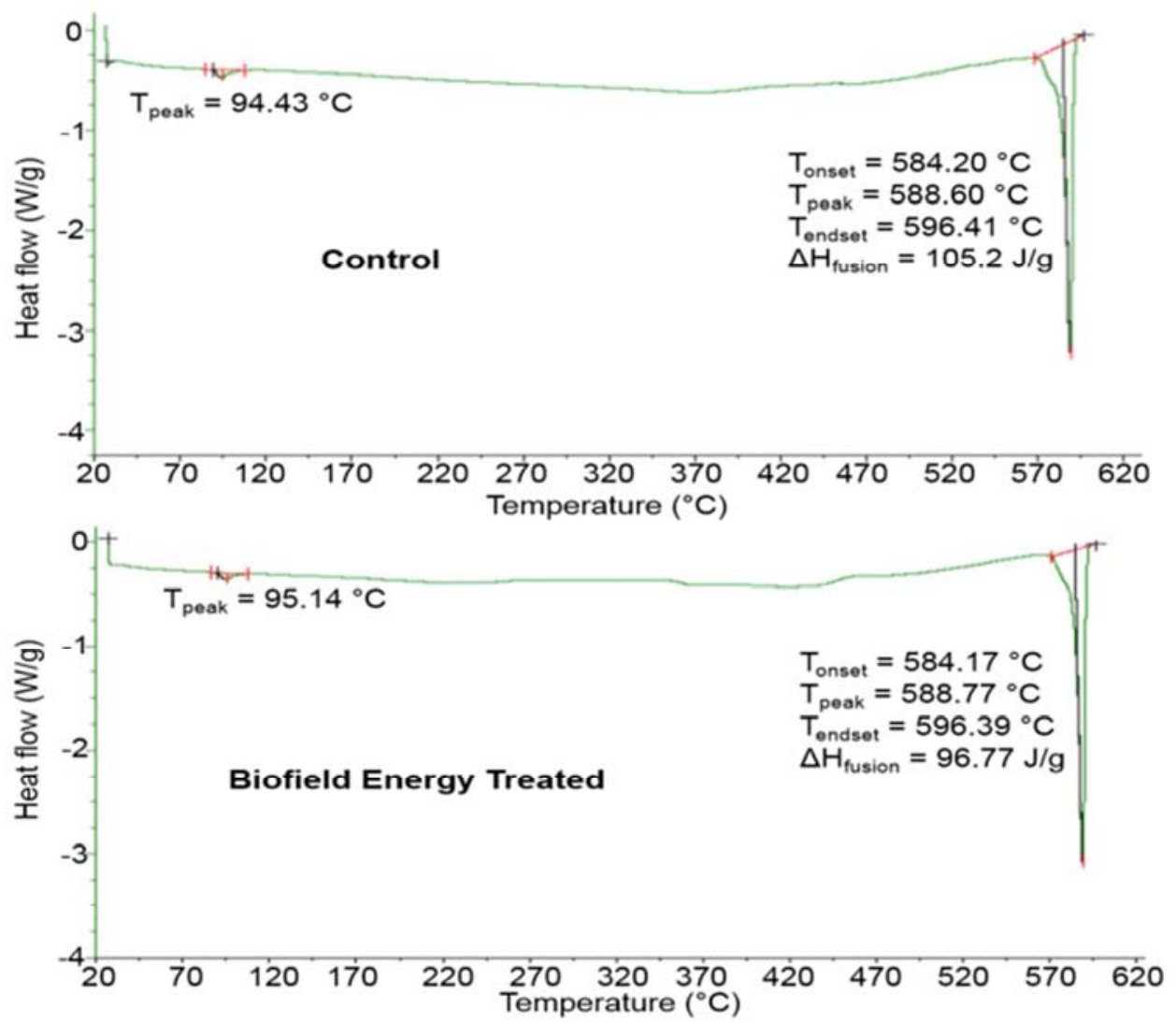

Figure 5. DSC thermograms of the control and Biofield Energy Treated sodium selenate.

Table 4. Comparison of DSC data between the control and Biofield Energy Treated sodium selenate.

\begin{tabular}{|c|c|c|c|c|c|}
\hline Entry No. & Sample & $\begin{array}{l}\text { Latent heat of fusion } \\
\left(\Delta \mathrm{H}_{\text {fusion }}\right) \mathrm{J} / \mathrm{g}\end{array}$ & $\begin{array}{l}\text { Onset melting } \\
\text { temperature }\left(\mathbf{T}_{\text {onset }}\right){ }^{\circ} \mathrm{C}\end{array}$ & $\begin{array}{l}\text { Peak melting } \\
\text { temperature }\left(\mathrm{T}_{\text {peak }}\right)^{\circ} \mathrm{C}\end{array}$ & $\begin{array}{l}\text { Endset melting } \\
\text { temperature }\left(\mathrm{T}_{\text {endset }}\right){ }^{\circ} \mathrm{C}\end{array}$ \\
\hline 1 & Control & 105.2 & 584.20 & 588.60 & 596.41 \\
\hline 2 & Biofield Energy Treated & 96.77 & 584.17 & 588.77 & 596.39 \\
\hline 3 & $\%$ Change* & -8.01 & -0.01 & 0.03 & 0.003 \\
\hline
\end{tabular}

$\mathrm{T}_{\text {onset }}$ : Onset melting temperature, $\mathrm{T}_{\text {peak }}$ : Peak melting temperature, $\mathrm{T}_{\text {endset }}$ : Endset melting temperature, $\Delta \mathrm{H}_{\text {fusion }}$ : Latent heat of fusion, ${ }^{*}$ denotes the percentage change of Biofield Energy Treated sample with respect to the control sample.

According to the DSC data and the reported literature, it is hypothesized that treated sample might be enantiotropic form of the untreated sodium selenate. The Biofield Energy Treated sodium selenate having lower the latent heat of fusion might be most stable and soluble polymorphic form at the temperatures below the transition point compared with the untreated sodium selenate [51-53].

\section{Conclusions}

The current investigation revealed that The Trivedi Effect $^{\circledR}$ - Energy of Consciousness Healing Treatment (Biofield Energy Healing Treatment) displayed the significant impact on the physicochemical and thermal properties of sodium selenate. The PXRD analysis showed the remarkable alteration of the crystallite size of the treated sample from $-36.36 \%$ to $133.24 \%$ compared with the control sample. Overall, the average crystallite size of the treated sodium selenate was decreased by $8.31 \%$ compared with the control sample. This result indicated that the crystal morphology of the treated sodium selenate was changed from the control sample and The Trivedi Effect ${ }^{\circledR}$ Biofield Energy Healing might lead to a new polymorphic form of sodium selenate. The particle sizes $d_{10}, d_{50}$, and $d_{90}$ values of the treated sample were significantly decreased by $3.40 \%, 9.75 \%$, and $8.52 \%$, respectively as compared to the 
control sample. Additionally, the surface area of the treated sample was increased by $5.26 \%$ from the control sample. TGA analysis revealed that the total weight loss of the treated sample was diminished by $1.24 \%$ compared with the control sample. The DSC analysis revealed that the treated sample $\left(588.77^{\circ} \mathrm{C}\right)$ had higher melting point than the control sample $\left(588.60^{\circ} \mathrm{C}\right)$. The latent heat of fusion of the treated sample was significantly decreased by $8.01 \%$ compared with the control sample. Briefly, the treated sodium selenate might be a new polymorphic form (i.e. enantiotropic) of sodium selenate having reduced crystallite and particle size and increased surface area. Thus, The Trivedi Effect ${ }^{\circledR}$ treated sodium selenate could be more soluble, bioavailable, and thermally stable than the control sample. Hence, treated sodium selenate would be very useful to design better nutraceutical and/or pharmaceutical formulations that might offer better therapeutic response against various diseases such as diabetes mellitus, allergies and septic shock; stress-related disorders like sleep disorder, insomnia, anxiety, depression, Attention Deficit Disorder (ADD), Attention Deficit Hyperactive Disorder (ADHD), mental restlessness (mind chattering), brain frog, low libido, impotency, lack of motivation, mood swings, fear of the future, confusion, migraines, headaches, forgetfulness, overwhelm, loneliness, worthlessness, indecisiveness, frustration, irritability, chronic fatigue, obsessive/compulsive behavior and panic attacks; inflammatory diseases and immunological disorders like Lupus, Systemic Lupus Erythematosus, Hashimoto Thyroiditis, Type 1. Diabetes, Asthma, Chronic peptic ulcers, Tuberculosis, Hepatitis, Chronic active hepatitis, Celiac Disease (gluten-sensitive enteropathy), Addison Disease, Crohn's disease, Graves' Disease, Pernicious and Aplastic Anemia, Sjogren Syndrome, Irritable Bowel Syndrome (IBS), Multiple Sclerosis, Rheumatoid arthritis, Chronic periodontitis, Ulcerative colitis, Chronic sinusitis, Myasthenia Gravis, Atherosclerosis, Vasculitis, Dermatitis, Diverticulitis, Rheumatoid Arthritis, Reactive Arthritis, Alopecia Areata, Psoriasis, Scleroderma, Fibromyalgia, Chronic Fatigue Syndrome and Vitiligo; aging-related diseases like cardiovascular disease, arthritis, cancer, Alzheimer's disease, dementia, cataracts, osteoporosis, diabetes, hypertension, glaucoma, hearing loss, Parkinson's Disease, Huntington's Disease, Prion Disease, Motor Neurone Disease, Spinocerebellar Ataxia, Spinal muscular atrophy, Amyotrophic lateral sclerosis, Friedreich's Ataxia and Lewy Body Disease; chronic infections and much more.

\section{Abbreviations}

DSC: Differential scanning calorimetry, FT-IR: Fourier transform infrared spectroscopy, FWHM: Full width half maximum, G: Crystallite size, HOMO: Highest energy occupied molecular orbital, LUMO: Lowest energy unoccupied molecular orbital, TGA: Thermal gravimetric analysis, $\mathrm{T}_{\text {onset }}$ : Onset melting temperature, $\mathrm{T}_{\text {peak }}$ : Peak melting temperature, $\mathrm{T}_{\text {endset }}$ : Endset melting temperature, $\Delta \mathrm{H}_{\text {fusion }}$ : Latent heat of fusion, UV-vis: Ultraviolet-visible spectroscopy, PSD: Particle size distribution; PXRD: Powder $\mathrm{X}$-ray diffraction.

\section{Acknowledgements}

The authors gratefully acknowledged to GVK Biosciences Pvt. Ltd., Trivedi Science, Trivedi Global, Inc. and Trivedi Master Wellness for the assistance and support during the work.

\section{References}

[1] Basnayake RST (2001) Inorganic selenium and tellurium speciation in aqueous medium of biological samples, Master of Science (Chemistry), December 2001, Sam Houston State University, Huntsville, Texas, 60 pp.

[2] Soruraddin MH, Heydari R, Puladvand M, Zahedi MM (2011) A new spectrophotometric method for determination of selenium in cosmetic and pharmaceutical preparations after preconcentration with cloud point extraction. Int $\mathrm{J}$ Anal Chem 2011: 729651.

[3] UmyFsová D, Vítová M, Doušková I, Bišová K, Hlavová M, Č́žková M, Machát J, Doucha J, Zachleder V (2009) Bioaccumulation and toxicity of selenium compounds in the green alga Scenedesmus quadricauda. BMC Plant Biol 9: 58.

[4] Gonzalez CM, Hernandez J, Peralta-Videa JR, Botez CE, Parsons JG, Gardea-Torresdey JL (2012) Sorption kinetic study of selenite and selenate onto a high and low pressure aged iron oxide nanomaterial. J Hazard Mater 211-212: 138145 .

[5] Sabaty M, Avazeri C, Pignol D, Vermeglio A (2001) Characterization of the reduction of selenate and tellurite by nitrate reductases. Appl Environ Microbiol 67: 5122-5126.

[6] Van Eersel J, Ke YD, Liu X, Delerue F, Kril JJ, Götz J, Ittner LM (2010) Sodium selenate mitigates tau pathology, neurodegeneration, and functional deficits in Alzheimer's disease models. Proc Natl Acad Sci USA 107: 13888-13893.

[7] Salama RM, Schaalan MF, Elkoussi AA, Khalifa AE (2013) Potential utility of sodium selenate as an adjunct to metformin in treating type II diabetes mellitus in rats: A perspective on protein tyrosine phosphatase. Biomed Res Int 2013: 231378.

[8] Ryan-Harshman M, Aldoori W (2005) The relevance of selenium to immunity, cancer, and infectious/inflammatory diseases. Can J Diet Pract Res 66: 98-102.

[9] https://en.wikipedia.org/wiki/Sodium_selenate.

[10] Krieger RI (2001) Handbook of Pesticide Toxicology, $2^{\text {nd }}$ Edn, Volume 1; Academic Press: San Diego, CA.

[11] Hanson B, Lindblom SD, Loeffler ML, Pilon-Smits E (2004) Selenium protects plants from phloem-feeding aphids due to both deterrence and toxicity. New Phytologist 162: 655-662.

[12] Haug A, Graham RD, Christophersen OA, Lyons GH (2007) How to use the world's scarce selenium resources efficiently to increase the selenium concentration in food. Microb Ecol Health Dis 19: 209-228. 
[13] Rubik B (2002) The biofield hypothesis: Its biophysical basis and role in medicine. J Altern Complement Med 8: 703-717.

[14] Nemeth L (2008) Energy and biofield therapies in practice. Beginnings 28: 4-5.

[15] Rivera-Ruiz M, Cajavilca C, Varon J (2008) Einthoven's string galvanometer: The first electrocardiograph. Tex Heart Inst J 35: 174-178.

[16] Koithan M (2009) Introducing complementary and alternative therapies. J Nurse Pract 5: 18-20.

[17] Trivedi MK, Tallapragada RM, Branton A, Trivedi D, Nayak G, Latiyal O, Jana S (2015) Effect of biofield energy treatment on physical and structural properties of calcium carbide and praseodymium oxide. International Journal of Materials Science and Applications 4: 390-395.

[18] Trivedi MK, Tallapragada RM, Branton A, Trivedi D, Nayak G, Latiyal O, Jana S (2015) Characterization of physical and structural properties of aluminium carbide powder: Impact of biofield treatment. J Aeronaut Aerospace Eng 4. 142.

[19] Trivedi MK, Branton A, Trivedi D, Nayak G, Bairwa K, Jana S (2015) Spectroscopic characterization of disulfiram and nicotinic acid after biofield treatment. J Anal Bioanal Tech 6: 265.

[20] Trivedi MK, Patil S, Shettigar H, Bairwa K, Jana S (2015) Spectroscopic characterization of biofield treated metronidazole and tinidazole. Med chem 5: 340-344.

[21] Trivedi MK, Tallapragada RM, Branton A, Trivedi D, Nayak G, Latiyal O, Mishra RK, Jana S (2015) Physicochemical characterization of biofield treated calcium carbonate powder. American Journal of Health Research 3: 368-375.

[22] Trivedi MK, Tallapragada RM, Branton A, Trivedi D, Nayak G, Latiyal O, Jana S (2015) Physical, atomic and thermal properties of biofield treated lithium powder. J Adv Chem Eng 5. 136.

[23] Trivedi MK, Branton A, Trivedi D, Nayak G, Bairwa K, Jana S (2015) Spectroscopic characterization of disodium hydrogen orthophosphate and sodium nitrate after biofield treatment. J Chromatogr Sep Tech 6: 282.

[24] Trivedi MK, Branton A, Trivedi D, Nayak G, Bairwa K, Jana S (2015) Fourier transform infrared and ultraviolet-visible spectroscopic characterization of ammonium acetate and ammonium chloride: An impact of biofield treatment. Mod Chem appl 3. 163.

[25] Trivedi MK, Branton A, Trivedi D, Nayak G, Bairwa K, Jana S (2015) Impact of biofield treatment on spectroscopic and physicochemical properties of $p$-nitroaniline. Insights in Analytical Electrochemistry 1: 1-8.

[26] Trivedi MK, Patil S, Shettigar H, Mondal SC, Jana S (2015) In vitro evaluation of biofield treatment on Enterobacter cloacae: Impact on antimicrobial susceptibility and biotype. J Bacteriol Parasitol 6. 241.

[27] Trivedi MK, Patil S, Shettigar H, Mondal SC, Jana S (2015) Evaluation of biofield modality on viral load of Hepatitis B and C viruses. J Antivir Antiretrovir 7. 083-088.

[28] Trivedi MK, Branton A, Trivedi D, Nayak G, Gangwar M, Jana S (2015) Improved susceptibility pattern of antimicrobials using vital energy treatment on Shigella sonnei.
American Journal of Internal Medicine 3. 231-237.

[29] Trivedi MK, Branton A, Trivedi D, Nayak G, Mondal SC, Jana S (2015) Morphological characterization, quality, yield and DNA fingerprinting of biofield treated alphonso mango (Mangifera indica L.). Journal of Food and Nutrition Sciences 3: $245-250$.

[30] Trivedi MK, Branton A, Trivedi D, Nayak G, Mondal SC, Jana S (2015) Evaluation of plant growth regulator, immunity and DNA fingerprinting of biofield treated mustard seeds (Brassica juncea). Agriculture, Forestry and Fisheries 4: 269274.

[31] Trivedi MK, Branton A, Trivedi D, Nayak G, Singh R, Jana S (2015) Physicochemical and spectroscopic characterization of biofield treated gerbera multiplication medium. Plant 3: 57-63.

[32] Trivedi MK, Branton A, Trivedi D, Nayak G, Mishra RK, Jana S (2015) Characterization of physical, thermal and spectral properties of Biofield Treated date palm callus initiation medium. International Journal of Nutrition and Food Sciences 4: 660-668.

[33] Trivedi MK, Branton A, Trivedi D, Nayak G, Mishra RK, Jana S (2015) Comparative physicochemical evaluation of biofield treated phosphate buffer saline and hanks balanced salt medium. American Journal of BioScience 3. 267-277.

[34] Trivedi MK, Patil S, Shettigar H, Bairwa K, Jana S (2015) Evaluation of phenotyping and genotyping characterization of Serratia marcescens after biofield treatment. J Mol Genet Med 9: 179.

[35] Trivedi MK, Branton A, Trivedi D, Nayak G, Charan S, Jana S (2015) Phenotyping and 16S rDNA analysis after biofield treatment on Citrobacter braakii: A urinary pathogen. J Clin Med Genom 3: 129.

[36] Chereson R (2009) Bioavailability, bioequivalence, and drug selection. In: Makoid CM, Vuchetich PJ, Banakar UV (Eds) Basic pharmacokinetics $\left(1^{\text {st }}\right.$ Edn) Pharmaceutical Press, London.

[37] Trivedi MK, Mohan TRR (2016) Biofield energy signals, energy transmission and neutrinos. American Journal of Modern Physics 5: 172-176.

[38] Chauhan A, Chauhan P (2014) Powder XRD technique and its applications in science and technology. J Anal Bioanal Tech 5: 212.

[39] Alexander L, Klug HP (1950) Determination of crystallite size with the X-Ray Spectrometer. J App Phys 21: 137.

[40] Langford JI, Wilson AJC (1978) Scherrer after sixty years: A survey and some new results in the determination of crystallite size. J Appl Cryst 11: 102-113.

[41] Inoue M, Hirasawa I (2013) The relationship between crystal morphology and XRD peak intensity on $\mathrm{CaSO}_{4} \cdot 2 \mathrm{H}_{2} \mathrm{O}$. J Crystal Growth 380: 169-175.

[42] Raza K, Kumar P, Ratan S, Malik R, Arora S (2014) Polymorphism: The phenomenon affecting the performance of drugs. SOJ Pharm Pharm Sci 1. 10.

[43] Blagden N, de Matas M, Gavan PT, York P (2007) Crystal engineering of active pharmaceutical ingredients to improve solubility and dissolution rates. Adv Drug Deliv Rev 59: 617630 . 
[44] Mosharrof M, Nyström C (1995) The effect of particle size and shape on the surface specific dissolution rate of microsized practically insoluble drugs. Int J Pharm 122: 3547.

[45] Khadka P, Ro J, Kim H, Kim I, Kim JT, Kim H, Cho JM, Yun G, Lee J (2014) Pharmaceutical particle technologies: An approach to improve drug solubility, dissolution and bioavailability. Asian J Pharm Sci 9. 304-316.

[46] Buckton G, Beezer AE (1992) The relationship between particle size and solubility. Int J Pharmaceutics 82: R7-R10.

[47] Stuart BH (2004) Infrared spectroscopy: Fundamentals and applications in Analytical Techniques in the Sciences. John Wiley \& Sons Ltd., Chichester, UK.

[48] Hesse M, Meier H, Zeeh B (1997) Spectroscopic methods in organic chemistry, Georg Thieme Verlag Stuttgart, New York.
[49] Bajaj S, Singla D, Sakhuja N (2012) Stability testing of pharmaceutical products. J App Pharm Sci 2. 129-138.

[50] Zhang M, Efremov MY, Schiettekatte F, Olson EA, Kwan AT, Lai SL, Wisleder T, Greene JE, Allen LH (2000) Sizedependent melting point depression of nanostructures: Nanocalorimetric measurements. Phys Rev B 62: 10548.

[51] Lee EH (2014) A practical guide to pharmaceutical polymorph screening \& selection. Asian J Pharm Sci 9. 163175.

[52] Thiruvengadam E, Vellaisamy G (2014) Polymorphism in pharmaceutical ingredients a review. World Journal of Pharmacy and Pharmaceutical Sciences 3: 621-633.

[53] Brittain HG (2009) Polymorphism in pharmaceutical solids in Drugs and Pharmaceutical Sciences, volume $192,2^{\text {nd }}$ Edn, Informa Healthcare USA, Inc., New York. 